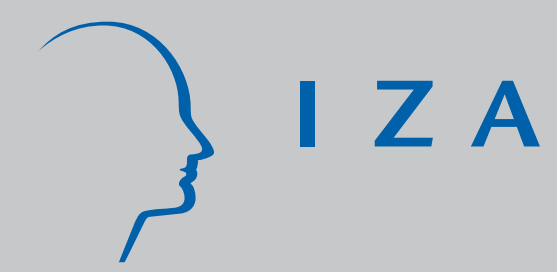

IZA DP No. 643

Parental Separation and Children's Educational Attainment: A Siblings Approach

Anders Björklund

Marianne Sundström

November 2002 


\title{
Parental Separation and Children's Educational Attainment: A Siblings Approach
}

\author{
Anders Björklund \\ SOFI, Stockholm University and IZA Bonn \\ Marianne Sundström \\ SOFI, Stockholm University
}

Discussion Paper No. 643
November 2002

\author{
IZA \\ P.O. Box 7240 \\ D-53072 Bonn \\ Germany \\ Tel.: +49-228-3894-0 \\ Fax: +49-228-3894-210 \\ Email: iza@iza.org
}

This Discussion Paper is issued within the framework of IZA's research area Evaluation of Labor Market Policies and Projects. Any opinions expressed here are those of the author(s) and not those of the institute. Research disseminated by IZA may include views on policy, but the institute itself takes no institutional policy positions.

The Institute for the Study of Labor (IZA) in Bonn is a local and virtual international research center and a place of communication between science, politics and business. IZA is an independent, nonprofit limited liability company (Gesellschaft mit beschränkter Haftung) supported by the Deutsche Post AG. The center is associated with the University of Bonn and offers a stimulating research environment through its research networks, research support, and visitors and doctoral programs. IZA engages in (i) original and internationally competitive research in all fields of labor economics, (ii) development of policy concepts, and (iii) dissemination of research results and concepts to the interested public. The current research program deals with (1) mobility and flexibility of labor, (2) internationalization of labor markets, (3) welfare state and labor market, (4) labor markets in transition countries, (5) the future of labor, (6) evaluation of labor market policies and projects and (7) general labor economics.

IZA Discussion Papers often represent preliminary work and are circulated to encourage discussion. Citation of such a paper should account for its provisional character. A revised version may be available on the IZA website (www.iza.org) or directly from the author. 
IZA Discussion Paper No. 643

November 2002

\section{ABSTRACT}

\section{Parental Separation and Children's Educational Attainment: A Siblings Approach*}

This article analyzes whether the commonly found negative relationship between parental separation in childhood and educational outcomes is causal or mainly due to selection. We use data on about 100,000 Swedish full biological siblings, born in 1951-64, and perform cross-section and sibling-difference estimations. Outcomes are measured as educational attainment in 1996. Our cross-section analysis show the expected negative and significant relationship, while the relationship is not significant, though precisely estimated, in the siblingdifference analysis. This finding was robust to the sensitivity tests performed and is consistent with selection, rather than causation, being the explanation for the negative relationship.

JEL Classification: J12, I20, I30

Keywords: divorce, child welfare, siblings estimators

Corresponding author:

Anders Björklund

Swedish Institute for Social Research

Stockholm University

10691 Stockholm

Sweden

Tel.: +468163452

Fax: +46 8154670

Email: Anders.Bjorklund@sofi.su.se

\footnotetext{
* We thank Donna Ginther, Oddbjorn Raaum and participants at the ESPE2001-meetings for valuable comments and the Swedish Council for Working Life and Social Research and the Joint Committee of the Nordic Social Science Research Councils for financial support.
} 


\section{Introduction}

In the last two decades much research attention has been paid to the relationship between childhood family structure and the educational attainment in adulthood. A common finding of many of these studies is that children who experienced a parental separation or grew up with a single parent incur educational disadvantages compared to those who grew up with both biological parents (see e.g. Jonsson \& Gähler 1997; McLanahan \& Sandefur 1994; for reviews see Amato \& Keith 1991 and Cherlin 1999). While recognizing the presence of selection effects, most previous studies have viewed this relationship as partly causal (e.g. Jonsson \& Gähler 1997). Recent work has, however, suggested that this negative association is due to selection rather than caus ation (see e.g. Ginther \& Pollak 2000). Clearly, the policy implications will differ depending on whether the mechanism is seen as selective or mainly causal (cf. Cherlin 1999).

The previous literature offers valid arguments for why both causal effects and selection mechanisms could explain the strong negative cross-sectional relationship between parental separation and educational achievement. Jonsson \& Gähler (1997), for example, discuss two main types of causal explanations for the link between family dissolution and children's educational careers. One is called the 'crises model' and stresses the emotional upheaval during the separation process, while the other focuses on the loss of one parent, including his/her income, social and human capital as well as his/her time.

The selection explanation of the cross-sectional relationship recognizes that many of the families that break up were worse off already before the separation. Most studies have attempted to take account of (some) pre-divorce characteristics, such as mother's age at birth, that is, factors that increase marital instability. They typically then find a substantial reduction in the educational disadvantage due to parental separation, but that the disadvantage remains (Fronstin, Greenberg \& Robins 2001; Jonsson \& Gähler 1997; McLanahan \& Sandefur 1994). 
That is, some of the factors that increase the risk of parental separation are also associated with lower educational attainment for children, which implies that at least part of the negative relationship is due to selection. In addition, intact families may not be the appropriate 'counterfactual' for evaluating the effect of parental separation on children's educational outcomes since the alternative for the couples who separate may not be to live happily together, but rather to live in conflict or to separate later. In fact, work by Gähler (1998) and Amato et al. (1995) suggest that children may be worse off by suffering parental conflict than by a separation.

In order to take differences in family background more efficiently into account and to analyze to what extent the association between parental separation and children's educational attainment is due to causation and selection, we use a sibling-difference approach. We use data on about 60,000 Swedes born in 1951-63 and their full biological siblings (about 50,000), all of whom have lived with both biological parents for at least some part of their childhood. We estimate both level equations and sibling-difference (fixed-effects) models. The latter models, which are our main contribution to this literature, identify the possible causal effect of separation by comparing the educational attainment of at least one older sibling, who was not directly affected by the separation, with that of at le ast one younger sibling who was.

The outline of the paper is as follows. In Section 2 we present the sibling-difference approach to the analysis of family-structure effects on child outcomes and review previous studies that have used this approach. Section 3 presents the data and the sample. In Section 4 we report our findings and the results of our sensitivity analysis. We end by a concluding discussion. 


\section{Sibling-difference studies of family structure effects}

The advantage with a sibling-difference approach to estimating the impact of family structure on subsequent outcomes is that any omitted variable capturing permanent family characteristics, which are shared by all siblings, cancel out of the estimated equation. As is well known, the presence of such variables will lead to bias in the cross-sectional estimates if they are correlated with the outcome of interest. Nonetheless, the sibling-difference approach is also associated with problems. First of all, the approach identifies the estimated effects from a subset of individuals, namely siblings who differ in their experiences of the childhood event of interest. Thus, only the subset of those who had siblings will be useful for identification. As a consequence, most survey-based household data sets have only a small number of sibling pairs who have such different experiences, which may lead to imprecise estimates. Our large register-based data set should, therefore, be particularly useful for a siblings-approach.

Further, the sibling-difference estimator is also impaired by potential biases. In their careful discussion of this estimator, Ermisch \& Francesconi (2001) mention two situations when this is the case. The first is when family structure - in our case a parental separation - is affected by the 'idiosyncratic endowments' of children. If, for example, the younger child is born with a disability that affects educational attainment and also brings about the separation, the estimated coefficient will not capture the causal separation effect. The second case is when any of the parents develop a problem - their example is that the father becomes addicted to alcohol - which does not directly affect the older sibling but does affect the younger one. If such a non-permanent problem causes the divorce and affects the younger sibling more than the older one, the separation coefficient in the sibling-difference model will be a biased estimate of the separation effect. The authors emphasize that these two sources of bias also plague the cross-sectional estimator, so they conclude that the underlying 
assumptions of the sibling-difference model in general are weaker than those underlying the cross-sectional estimator. These should also be weaker in our study than, for example, in the study by Ermisch \& Francesconi (2001) since we compare full siblings who have all lived with both parents for at least part of their childhood while they also compare half siblings.

The sibling-approach has recently been used in a number of related empirical studies, although we are not aware of any study that focuses solely on the impact of parental separation in the way we do. Ermisch \& Francesconi (2001), Case, Lin \& McLanahan (2000) and Ginther \& Pollak (2000) study the effect of family structure on children's educational attainment as adults. Using UK data Ermisch \& Francesconi (2001) found that having lived with a single (or divorced) mother as a child significantly lowered (by about 14 percent) the child's probability of achieving A-level qualification according to both the cros s-section model and the fixed-effects model. The effect was strongest if the child had lived with a single/divorced mother in early childhood. However, they cannot distinguish the effect of a parental separation in early childhood from that of being born outside of a marriage/cohabitation. Case et al. (2000) compare the educational attainment of women's birth and non-birth children. Controlling for the woman's fixed-effects, they find that children raised by a step, adoptive or foster mother obtain signific antly less education on average than do the birth children of the same woman.

Ginther \& Pollak (2000) compared the educational outcomes of half siblings from stable blended families where at least one of the siblings lived with both biological parents. They found that, on average, children from intact families did better, but within stable blended families there was no significant difference in educational outcomes between the stepchildren and the biological children. This finding is consistent with both the selection hypothesis and the disruption hypothesis (i.e., the 'crises model'). 


\section{Data and sample}

\subsection{Data and variables}

Our data set is based on a random sample of the Swedish population born in Sweden between 1951 and 1963. ${ }^{1}$ We require that these persons lived in Sweden in 1992. The sample size is 93,333 persons. By means of the population registers at Statistics Sweden we identify the siblings of these persons. The data allow us to distinguish full siblings from half siblings and siblings who are rehted through adoptions. In our sibling analysis we use only full siblings while indicators on the presence of half siblings are included in the cross-section analysis (see below). During childhood—defined as 0-17 years of age — we observe the sampled persons and their full siblings in the censuses in 1960, 1965, 1970, 1975 and 1980. We also observe whether their biological parents, other adults, or other children (also aged 0-17 years) live in the same household, but we make no distinction between formally married parents and parents who live in a consensual union. A separation has occurred when we no longer observe the child living with both parents in the census. ${ }^{2} \mathrm{We}$ assume that the separation occurs in the middle year between the censuses and measure age at separation as the average of the age in the census where the child was observed with both parents and the age in the censuses in which it was not observed with both parents. Since the earliest census we have access to is the one from 1960, we cannot observe separations occurring before age nine for those born in 1951 (and not before age eight for those born in 1952 etc.), but we investigate how sensitive our results are to this limitation by estimating the models without the cohorts born before 1959 (see Section 4.3).

We impose a few more restrictions on the final sample that we use in the siblingdifference analysis. First, we require that each sibling lived together with both biological

\footnotetext{
${ }^{1}$ Björklund et al. (2002) present the larger data set from which our sample is drawn.

${ }^{2}$ Limiting childhood to ages below 18 should not be a problem since higher education is free in Sweden and college and university students can receive student loans and allowances. Also, in Sweden you come of age at age 18 .
} 
parents in the first census in which they were observed. In so doing, we only use observations on individuals who have been exposed to the risk of separation from both parents. Second, we require that each sampled person and his/her sibling(s) can be observed in at least two censuses, but not necessarily the same ones. Therefore, we do not use siblings born before 1948 as observations. Third, we require that both parents were alive and lived in Sweden at the time of the last census in which the child was observed. By applying this restriction, we focus on separations due to family dissolution rather than separations due to death or emigration of a parent. Fourth, we also exclude children who had at least one parent born abroad. These additional restrictions reduce the random sample to about 62,000 and the sibling sample to about 50,000, which implies about 104,000 observations in the siblingdifference analysis.

We measure outcomes in 1996, so siblings are 33-48 years of age when they are observed as adults. We follow much of the previous literature by using educational attainment as our outcome measure. The education information stems from the education register that Statistics Sweden holds for research purposes. At this time, the education register had good coverage of the whole population and contained information about both level and field of education. Furthermore, in order to condense the information on educational achievement into one measure, we construct an index of 'earnings-weighted education' by estimating a log annual-earnings equation on dummies for all levels and fields of education plus dummies for age and gender. This equation is estimated on a sample of the adult population. We define the individual's earnings-weighted education as the coefficient on the dummy variable that indicates the individual's level and field of education, see Björklund \& Richardson (2001) for further details.

In both the cross-section analysis and the sibling-difference analysis we include variables that are likely to influence children's educational outcomes and the risk of parental 
separation. Thus, in addition to age and gender variables we include indicators of whether, subsequent to any separation, the individual lived with their mother or father or with neither parent. Further, in the cross-section analysis we include dummy variable s on whether or not the individual had any older half siblings, and whether these had the same mother or the same father as the individual. Also, we include information on the number of older full siblings. We use only indicators of older full siblings and any older half siblings since their presence is independent of the parent's decision to separate during the childhood of our sampled individual, while the presence of any younger full or half siblings is not. These variables will, of course, cancel out in the sibling-difference analysis. Finally, we include indicators of the age of the parents at the individual's birth. In particular, we include a dummy variable, 'teenage mum', which is equal to one if the mother was 18 years or younger when the individual was born and an indicator, 'old dad', of whether the father was 45 years or older.

\subsection{Sample characteristics}

We present means and frequencies for the random sample and the sibling sample in Table 1. We see, for example, that the fraction of persons who experienced a parental separation increases over birth cohorts. Further, the mean number of full siblings is higher in the siblings sample than in the random sample, which is as expected since persons who have many siblings are more likely to be drawn into that sample and persons without siblings are only found in the random sample. Consistently, there is a higher frequency of separations in the random sample and the mean number of half siblings is also higher.

Turning to Table 2 we observe some interesting differences between individuals who experienced a parental separation and those who did not. For example, in both samples the persons who experienced a separation during childhood more often had a mother who gave

birth before she was 19 , they less often had a dad who was 45 years or older when they were born and thus, on average, their parents were younger. Further, they had more half siblings 
and more older half siblings on both the mother's and the father's side. Finally, individuals who experienced a family dissolution had lower earnings-weighted education, on average.

\section{Results}

\subsection{Cross-section estimates}

We start by estimating a set of cross-section equations of the relationship between parental separation during childhood and educational attainment, measured as earnings - weighted education in 1996, for our random sample. In line with previous studies, the results show that parental separation indeed has a statistically significant negative association with educational attainment in adulthood (Table 3a, Model 1). The coefficient of about -.045 corresponds to about one year of schooling and also to approximately one quarter of a standard deviation of the education variable. However, we find no significant impact of age at separation (Model

2). ${ }^{3}$ We then investigate how the separation coefficient is affected when we adjust for characteristics of the family of origin. To that end, we include, first, mother's age at childbirth (a dummy for teenage birth and a linear age term), father's age at childbirth (a dummy for having an older father and a linear age term) and indicators for the presence of any older halfsiblings on mother's side and on father's (Model 3). We then see that the separation coefficient is reduced by about one-third, but still remains statistically significant. As expected, the impact of mother's age at birth is positive, while that of having a teenage mother is negative. Father's age at birth has a negative effect, as does having an older dad. In line with Ginther \& Pollak (2000), we find that the presence of any older half siblings affects educational outcomes negatively, but interestingly, more negatively for half siblings on mother's side. Since older half siblings on the mother's side are more likely to live with the sampled individual, a possible interpretation of this result is that domestic conflict and

\footnotetext{
${ }^{3}$ We also experimented with dummy variables for age at separation but still found no effect.
} 
competition over mother's time has a greater impact on educational outcomes than any child support paid by the father to the half siblings on his side. Next, we include number of older full siblings (Model 4). (As mentioned, the reason for including only older full siblings and older half siblings is that the number of younger full siblings and half siblings is endogenous with respect to parental separation.) The separation coefficient then turns more negative again. This is because the presence of older full siblings increases marital stability while the presence of older half siblings increases the risk of separation. Finally, there is no impact of whether the individual lived with the mother or the father after the separation (Model 5).

We also estimated the same models for the sibling sample. While the direction of the effects is similar for the two samples, there are also some interesting differences (Table 3b). For example, the negative effect of separation is smaller (in Model 1) than for the random sample and age at separation is positive and significant, given the larger negative effect of separation (Model 2). These differences spur our interest in analyzing whether there is any difference between siblings in educational outcomes when at least one sibling experienced a parental separation while at least one did not. Thereby, we control for permanent characteristics of family background shared by the siblings and obtain an estimate of any causal effect of parental separation on educational outcomes.

\subsection{Sibling-difference estimates}

The results from our sibling-difference analysis of the association between educational outcomes as adult and experience o parental separation during childhood are presented in Table 4. We see that the separation coefficient is strikingly different from the one in the crosssection analysis. The latter was -.0449 (std. err. 0.0028) in Model 1, suggesting that the highest limit of a $95 \%$ confidence interval is -.0396 . The sibling-difference estimate is instead positive but close to zero, .0038 , in Model 1. Although the standard error is higher, .0058 , a $95 \%$ confidence interval suggests a lower limit of -.0076. Even this number implies 
a quite low causal negative effect of separation. (As the mean age of separation is about nine years, the separation coefficient does not change much across models).

Consequently, we do not find any effect of age at separation either. As to the control variables, we find no effect of which parent the child lived with after divorce (Model 4). A person who had a teenage mother did not incur any educational disadvantage compared to a younger sibling(s) who had not. This suggests that the negative and significant cross-section estimate for teenage mother reflects selection rather than causation. Although we find this result interesting, we are also aware of the fact that many teenage births do not show up in our sample due to our restriction that the child must have been observed with both parents in at least one census. ${ }^{4}$ Further, a person who had an older dad had a small, but significant, educational advantage over an older sibling.

\subsection{Sensitivity analysis}

Are there any other possible explanations than selection for the difference between the separation coefficients in the cross-section analysis and the sibling-difference analysis? In the following we investigate some potential flaws in our analysis. First, is it the case that the coefficients on separation and age at separation are different for those born in 1959 or later than for the older cohorts (for which we could not observe any parental separation before 1960)? No, the cross-section estimates are highly similar (Table 5) and the sibling-difference estimates (Table 6) point to a small positive effect of separation, which is weakly significant only in Model 1. Age at separation is not significant in any of the models.

Second, is the discrepancy between the cross-section and the fixed-effect estimates driven by the separation coefficient being more negative and more significant for persons without siblings? No, this is not the case either. Although the separation coefficient is somewhat more negative in Model 1 (Table 7) than for the whole random sample (cf. Table 
3a), it turns insignificant when family background characteristics are taken into account (Model 4) which was not the case for the whole random sample.

Third, is it possible that difference in results is caused by the siblings being too close in age, so that they are all equally (badly) affected by the family crisis that lead to the separation? We investigate this hypothesis by re-estimating the sibling-difference model only on siblings among whom the age difference was five years or more, but still find no significant effect of separation (Table 8).

A fourth possibility is that the discrepancy between the cross-section and the siblingdifference estimates is due to birth-order effects. This could be the case if, on average, the younger siblings, who are the ones mainly affected by a separation, have better educational outcomes. We test this hypothesis through a re-estimation of the sibling-difference model with indicators for birth-order (oldest, youngest) included. The results show that, in fact, the younger siblings do wor se and that the separation coefficient is still insignificant (Table 9).

Finally, it is possible that the individuals in families who identify the separation coefficient in the difference-model, that is, those whose parents separated and among whom at least one had left home at the time of separation, are too few, or deviant in a way that drives the result. In order to investigate this possibility we present means and frequencies and estimate the cross-section model for these siblings. The characteristics of these individuals (see Appendix) do not differ much from those of the individuals in the random sample and the siblings sample who experienced a parental separation (cf. Table 2), except that the former individuals had more full siblings and fewer half siblings. Clearly, the cross-section estimates differ a good deal from those for the random sample which is as expected since these individuals come from the same families. (Table 10, cf. Table 3a). First of all, the separation coefficient is smaller and insignificant in Model 1, and when age at separation is included in

\footnotetext{
${ }^{4}$ Teenage births are, however, more rare in Sweden than, for example, in the U.S. or the U.K. (Santow \&
} 
Model 2 it becomes more negative, but is still insignificant, as is age of separation. On the other hand, when controls are made for age of parents at childbirth and older half-siblings (Model 3), the separation coefficient becomes more negative and significant, and age at separation becomes positive and significant (at the 10\%-level). These coefficients, however, turn insignificant in Model 4 and 5 when further controls for family background are made.

We see, for example, that for the identifying siblings living with the father after a separation is associated with a less favorable educational outcome than living with the mother. These results are in contrast with the results for the random sample but consistent with the results in the sibling-difference analysis.

\section{Concluding discussion}

This paper has used a siblings approach to analyze whether the commonly found negative association between experience of parental separation during childhood and educational outcomes as adult is causal or mainly due to selection. To that end, we used data on about 100,000 Swedes born in 1951-64 who were full biological siblings and have all lived with both biological parents for some period of childhood and performed both cross-sectional and sibling-differences analyses. Educational outcomes were measured in 1996. Our crosssectional analysis replicated what most previous researchers have found, namely that persons who experienced a parental separation in childhood incur educational disadvantages compared to those who grew up with both biological parents. Our measure of educational attainment as adult reflects the labor-market return to the highest level and field of education attained and the cross sectional gap associated with a parental separation is equivalent to the average rate of return to one year of schooling in Sweden. When we included some observable correlates of marital instability, such as whether or not the mother gave birth as a

Bracher 1999). 
teenager and presence of older half siblings, the cross-sectional gap decreased by about onethird. However, when we applied a sibling-difference model that also takes account of unobservable characteristics shared by siblings, we found no impact of parental separation. Thus, an older sibling who lived with both parents during his/her childhood did not have an educational advantage over a younger sibling who experienced a separation in childhood. This finding was robust with respect to a number of sensitivity checks.

Our conclusion that there are no causal separation effects contrasts the recent study by Jonsson \& Gähler (1997) that also uses Swedish data. We believe the results diverge because the sibling-difference technique controls more efficiently for family background characteristics than their regression approach, which uses controls on observables such as parental occupation and income. Nonetheless, we note one important difference between the two studies. Whereas they use short-run outcomes, namely Grade-Point Average at age 16 and the probability of continuing from primary to upper secondary school, we use educational attainment in adulthood. Perhaps, the distinction between temporary and permanent effects of parental separation is a useful one for future research on this topic. 


\section{REFERENCES}

Amato, P.R. and Keith, B. (1991), Parental divorce and adult well-being: A meta-analysis. Journal of Marriage and the Family 55:23-41.

Amato, P.R., Loomis, L. S. and Booth, A. (1995), Parental divorce, marital conflict, and offspring well-being during early adulthood, Social Forces 73: 895-915.

Björklund, A. and Richardson, K. (2001), The educational attainment of adopted children born abroad - Swedish evidence. Paper presented to the $15^{\text {th }}$ ESPE-meetings, Athens, June 2001.

Björklund A., T. Eriksson, M. Jäntti, O. Raaum and E. Österbacka (2002) Brother correlations in earnings in Denmark, Finland, Norway, and Sweden compared to the United States. Journal of Population Economics, vol 4.

Case, A., Lin I. and McLanahan, S. (2000), Educational attainment in blended families, Evolution and Human Behavior, 22(4), Sept. 2001): 269-289.

Cherlin, A.J. (1999), Going to the Extremes: Family Structure, Children's Well-Being, and Social Science, Demography vol. 36(4), 421-428.

Ermisch, J.F. and Franseconi, M. (2001), Family structure and children's achievements, Journal of Population Economics 14:249-70.

Fronstin, P., Greenberg, D.H. and Robins, P. K. (2001), Parental disruption and the labour market performance of children when they reach adulthood, Journal of Population Economics 14:137-172.

Ginther, D.K. and Pollak, R.A. (2000), Does family structure affect children's educational outcomes? Working Paper 2000-13a, Federal Reserve Bank of Atlanta.

Gähler, M. (1998), Self-reported psychologic al well-being among adult children of divorce in Sweden, Acta Sociologica 41 (3).

Santow, G. and Bracher, M. (1999), Explaining trends in teenage childbearing in Sweden, Studies in Family Planning 30: 169-182.

Jonsson, J.O. and Gähler M. (1997), Family dis solution, family reconstitution, and children's educational careers: Recent evidence for Sweden, Demography 34:277-293.

McLanahan, S. and Sandefur, G. (1994), Growing up with a single parent Cambridge: Harvard University Press. 
Table 1. Means and frequencies of the random sample and the siblings sample. Standard deviations for earnings-weighted education in parentheses.

\begin{tabular}{|c|c|c|c|c|c|c|c|c|}
\hline & \multicolumn{4}{|c|}{ The random sample } & \multicolumn{4}{|c|}{ The siblings } \\
\hline & $\underline{\text { Born }}$ & $\underline{\text { Born }}$ & $\underline{\text { Born }}$ & $\underline{\text { All }}$ & $\underline{\text { Born }}$ & $\underline{\text { Born }}$ & $\underline{\text { Born }}$ & All \\
\hline Female & 0.491 & 0.491 & 0.487 & 0.489 & 0.489 & 0.484 & 0.486 & 0.486 \\
\hline Separation $^{\mathrm{a}}$ & 0.033 & 0.066 & 0.097 & 0.068 & 0.018 & 0.046 & 0.072 & 0.047 \\
\hline Age at sep ${ }^{b}$ & 10.9 & 8.6 & 7.4 & 8.8 & 12.1 & 9.9 & 8.6 & 9.4 \\
\hline M.'s age at birth & 28.5 & 28.2 & 27.6 & 28.1 & 26.1 & 27.1 & 28.7 & 27.3 \\
\hline Teenage mum & 0.021 & 0.025 & 0.032 & 0.027 & 0.033 & 0.024 & 0.013 & 0.023 \\
\hline Old dad & 0.041 & 0.042 & 0.038 & 0.040 & 0.038 & 0.027 & 0.040 & 0.028 \\
\hline Mother aft. sep. ${ }^{b}$ & 0.774 & 0.836 & 0.822 & 0.819 & 0.866 & 0.905 & 0.877 & 0.886 \\
\hline Father aft. sep. ${ }^{b}$ & 0.111 & 0.109 & 0.134 & 0.124 & 0.087 & 0.078 & 0.105 & 0.094 \\
\hline No parent aft sep & 0.114 & 0.055 & 0.043 & 0.057 & 0.047 & 0.016 & 0.016 & 0.020 \\
\hline \# of full siblings & 1.72 & 1.73 & 1.68 & 1.71 & 2.76 & 2.59 & 2.48 & 2.60 \\
\hline \# of older full sib & 0.99 & 1.12 & 1.46 & 1.22 & 0.77 & 1.27 & 2.05 & 1.39 \\
\hline \# of half siblings & 0.173 & 0.259 & 0.307 & 0.252 & 0.156 & 0.227 & 0.252 & 0.214 \\
\hline $\begin{array}{l}\text { Any older half } \\
\text { siblings mum's }\end{array}$ & 0.059 & 0.078 & 0.073 & 0.070 & 0.054 & 0.065 & 0.061 & 0.060 \\
\hline $\begin{array}{l}\text { Any older half } \\
\text { siblings dad's }\end{array}$ & 0.033 & 0.052 & 0.061 & 0.050 & 0.037 & 0.050 & 0.056 & 0.048 \\
\hline $\begin{array}{l}\text { Earnings-weight. } \\
\text { education }\end{array}$ & $\begin{array}{c}0.216 \\
(0.176)\end{array}$ & $\begin{array}{l}0.215 \\
(0.175)\end{array}$ & $\begin{array}{c}0.218 \\
(0.177)\end{array}$ & $\begin{array}{c}0.217 \\
(0.176 \\
)\end{array}$ & $\begin{array}{c}0.201 \\
(0.178)\end{array}$ & $\begin{array}{c}0.203 \\
(0.171)\end{array}$ & $\begin{array}{c}0.206 \\
(0.174)\end{array}$ & $\begin{array}{r}0.203 \\
(0.174)\end{array}$ \\
\hline \# of observations & 18,302 & 18,880 & 24,485 & 61,667 & 15,375 & 17,076 & 17,726 & 50,177 \\
\hline
\end{tabular}

Notes: ${ }^{a}$ We assume that separations occur in between the two censuses. ${ }^{b}$ Conditional on separation. 
Table 2. Sample characteristics by experience of parental separation. Standard-deviations for earnings-weighted education in parentheses.

\begin{tabular}{|c|c|c|c|c|}
\hline & \multicolumn{2}{|c|}{ The random sample } & \multicolumn{2}{|c|}{$\begin{array}{c}\text { The siblings } \\
\end{array}$} \\
\hline & No separation & Separation & No separation & Separation \\
\hline Teenage mum & 0.024 & 0.061 & 0.022 & 0.037 \\
\hline Old dad & 0.041 & 0.026 & 0.028 & 0.023 \\
\hline Mother's age at birth & 28.2 & 25.7 & 27.4 & 26.0 \\
\hline Father's age at birth & 31.6 & 29.1 & 31.0 & 29.4 \\
\hline \# of full siblings & 1.73 & 1.48 & 2.62 & 2.36 \\
\hline \# older full siblings & 1.22 & 1.19 & 1.38 & 1.54 \\
\hline \# of half siblings & 0.19 & 1.16 & 0.17 & 1.05 \\
\hline $\begin{array}{l}\text { Any older half } \\
\text { siblings mum's side }\end{array}$ & 0.067 & 0.117 & 0.058 & 0.102 \\
\hline $\begin{array}{l}\text { Any older half } \\
\text { siblings dad's side }\end{array}$ & 0.046 & 0.096 & 0.046 & 0.098 \\
\hline $\begin{array}{l}\text { Earnings- weighted } \\
\text { education }\end{array}$ & $\begin{array}{c}0.220 \\
(0.178)\end{array}$ & $\begin{array}{r}0.176 \\
(0.150)\end{array}$ & $\begin{array}{r}0.205 \\
(0.176)\end{array}$ & $\begin{array}{c}0.173 \\
(0.148)\end{array}$ \\
\hline \# of observations & 57,461 & 4,206 & 47,833 & 2,344 \\
\hline
\end{tabular}


Table 3a Cross-section regressions. Dependent variable: earnings- weighted education. The random sample. (Standard errors in parentheses.). $\mathrm{N}=61,667$.

\begin{tabular}{|c|c|c|c|c|c|}
\hline & Model 1 & Model 2 & Model 3 & Model 4 & Model 5 \\
\hline Constant & $\begin{array}{r}0.4367 \\
(0.0856)\end{array}$ & $\begin{array}{c}0.4363 \\
(0.0856)\end{array}$ & $\begin{array}{c}0.3754 \\
(0.0850)\end{array}$ & $\begin{array}{c}0.6033 \\
(0.0842)\end{array}$ & $\begin{array}{c}0.6027 \\
(0.0843)\end{array}$ \\
\hline Age & $\begin{array}{c}-0.0103 \\
(0.0044)\end{array}$ & $\begin{array}{l}-0.0103 \\
(0.0044)\end{array}$ & $\begin{array}{c}-0.0099 \\
(0.0044)\end{array}$ & $\begin{array}{l}-0.0201 \\
(0.0044)\end{array}$ & $\begin{array}{l}-0.0201 \\
(0.0043)\end{array}$ \\
\hline Age sq./1000 & $\begin{array}{c}0.1236 \\
(0.0568)\end{array}$ & $\begin{array}{c}0.1234 \\
(0.0568)\end{array}$ & $\begin{array}{c}0.1136 \\
(0.0564)\end{array}$ & $\begin{array}{c}0.2255 \\
(0.0558)\end{array}$ & $\begin{array}{c}0.2252 \\
(0.0559)\end{array}$ \\
\hline Female & $\begin{array}{c}-0.0109 \\
(0.0014)\end{array}$ & $\begin{array}{l}-0.0109 \\
(0.0014)\end{array}$ & $\begin{array}{c}-0.0110 \\
(0.0014)\end{array}$ & $\begin{array}{l}-0.0101 \\
(0.0014)\end{array}$ & $\begin{array}{l}-0.0102 \\
(0.0013)\end{array}$ \\
\hline Separation & $\begin{array}{c}-0.0449 \\
(0.0028)\end{array}$ & $\begin{array}{l}-0.0417 \\
(0.0090)\end{array}$ & $\begin{array}{c}-0.0288 \\
(0.0089)\end{array}$ & $\begin{array}{c}-0.0376 \\
(0.0088)\end{array}$ & $\begin{array}{c}-0.0371 \\
(0.0089)\end{array}$ \\
\hline Age at separation & & $\begin{array}{r}-0.00036 \\
(0.00096)\end{array}$ & $\begin{array}{l}-0.0007 \\
(0.0096)\end{array}$ & $\begin{array}{c}0.00030 \\
(0.00095)\end{array}$ & $\begin{array}{c}0.00034 \\
(0.00096)\end{array}$ \\
\hline Mum's age at birth & & & $\begin{array}{c}0.0036 \\
(0.0002)\end{array}$ & $\begin{array}{c}0.0040 \\
(0.0002)\end{array}$ & $\begin{array}{c}0.0040 \\
(0.0002)\end{array}$ \\
\hline Teenage mum & & & $\begin{array}{c}-0.0328 \\
(0.0046)\end{array}$ & $\begin{array}{l}-0.0295 \\
(0.0045)\end{array}$ & $\begin{array}{l}-0.0295 \\
(0.0045)\end{array}$ \\
\hline Dad's age at birth & & & $\begin{array}{c}-0.0011 \\
(0.0002)\end{array}$ & $\begin{array}{l}-0.0005 \\
(0.0002)\end{array}$ & $\begin{array}{l}-0.0005 \\
(0.0002)\end{array}$ \\
\hline Old dad (>44 at birth) & & & $\begin{array}{c}-0.0226 \\
(0.0042)\end{array}$ & $\begin{array}{l}-0.0211 \\
(0.0041)\end{array}$ & $\begin{array}{l}-0.0211 \\
(0.0041)\end{array}$ \\
\hline Any older half sibs, mum & & & $\begin{array}{c}-0.0508 \\
(0.0028)\end{array}$ & $\begin{array}{l}-0.0590 \\
(0.0028)\end{array}$ & $\begin{array}{l}-0.0590 \\
(0.0028)\end{array}$ \\
\hline Any older half sibs, dad & & & $\begin{array}{c}-0.0156 \\
(0.0033)\end{array}$ & $\begin{array}{l}-0.0206 \\
(0.0032)\end{array}$ & $\begin{array}{l}-0.0207 \\
(0.0032)\end{array}$ \\
\hline Older full sibs & & & & $\begin{array}{c}-0.0245 \\
(0.0006)\end{array}$ & $\begin{array}{c}-0.0245 \\
(0.0007)\end{array}$ \\
\hline With father after separation & & & & & $\begin{array}{l}-0.0037 \\
(0.0082)\end{array}$ \\
\hline With neither parent after sep. & & & & & $\begin{array}{c}0.0074 \\
(0.0116)\end{array}$ \\
\hline Adj R-sq. & 0.005 & 0.005 & 0.020 & 0.042 & 0.042 \\
\hline
\end{tabular}


Table 3b. Cross-section regressions. Dependent variable: earnings-weighted education. The siblings. (Standard errors in parentheses.) $\mathrm{N}=50,177$.

\begin{tabular}{|c|c|c|c|c|c|}
\hline & Model 1 & Model 2 & Model 3 & Model 4 & Model 5 \\
\hline Constant & $\begin{array}{c}0.2748 \\
(0.0675)\end{array}$ & $\begin{array}{c}0.2784 \\
(0.0675)\end{array}$ & $\begin{array}{c}0.1322 \\
(0.0673)\end{array}$ & $\begin{array}{c}0.3618 \\
(0.0665)\end{array}$ & $\begin{array}{c}0.3622 \\
(0.0665)\end{array}$ \\
\hline Age & $\begin{array}{l}-0.0025 \\
(0.0034)\end{array}$ & $\begin{array}{l}-0.0027 \\
(0.0034)\end{array}$ & $\begin{array}{c}0.0005 \\
(0.0033)\end{array}$ & $\begin{array}{c}-0.0088 \\
(0.0033)\end{array}$ & $\begin{array}{c}-0.0088 \\
(0.0032)\end{array}$ \\
\hline Age sq./1000 & $\begin{array}{c}0.0225 \\
(0.0413)\end{array}$ & $\begin{array}{c}0.0240 \\
(0.0413)\end{array}$ & $\begin{array}{c}0.0073 \\
(0.0410)\end{array}$ & $\begin{array}{c}0.0737 \\
(0.0404)\end{array}$ & $\begin{array}{c}0.0741 \\
(0.0404)\end{array}$ \\
\hline Female & $\begin{array}{l}-0.0081 \\
(0.0016)\end{array}$ & $\begin{array}{l}-0.0081 \\
(0.0016)\end{array}$ & $\begin{array}{l}-0.0078 \\
(0.0015)\end{array}$ & $\begin{array}{c}-0.0078 \\
(0.0015)\end{array}$ & $\begin{array}{c}-0.0078 \\
(0.0015)\end{array}$ \\
\hline Separation & $\begin{array}{l}-0.0342 \\
(0.0037)\end{array}$ & $\begin{array}{l}-0.0603 \\
(0.0128)\end{array}$ & $\begin{array}{c}-0.0493 \\
(0.0127)\end{array}$ & $\begin{array}{c}-0.0476 \\
(0.0125)\end{array}$ & $\begin{array}{c}-0.0471 \\
(0.0126)\end{array}$ \\
\hline Age at separation & & $\begin{array}{c}0.0028 \\
(0.0013)\end{array}$ & $\begin{array}{c}0.0026 \\
(0.0013)\end{array}$ & $\begin{array}{c}0.0024 \\
(0.0013)\end{array}$ & $\begin{array}{c}0.0026 \\
(0.0013)\end{array}$ \\
\hline Mum's age at birth & & & $\begin{array}{c}0.0041 \\
(0.0002)\end{array}$ & $\begin{array}{c}0.0049 \\
(0.0002)\end{array}$ & $\begin{array}{c}0.0049 \\
(0.0002)\end{array}$ \\
\hline Teenage mum & & & $\begin{array}{l}-0.0267 \\
(0.0054)\end{array}$ & $\begin{array}{c}-0.0235 \\
(0.0053)\end{array}$ & $\begin{array}{c}-0.0235 \\
(0.0053)\end{array}$ \\
\hline Dad's age at birth & & & $\begin{array}{l}-0.0121 \\
(0.0002)\end{array}$ & $\begin{array}{c}-0.0004 \\
(0.0002)\end{array}$ & $\begin{array}{c}-0.0003 \\
(0.0002)\end{array}$ \\
\hline Older dad (> 44 at birth) & & & $\begin{array}{c}-0.0304 \\
(0.0053)\end{array}$ & $\begin{array}{c}-0.0280 \\
(0.0052)\end{array}$ & $\begin{array}{c}-0.0281 \\
(0.0053)\end{array}$ \\
\hline Any older half sibs, mum & & & $\begin{array}{l}-0.0566 \\
(0.0032)\end{array}$ & $\begin{array}{c}-0.0591 \\
(0.0032)\end{array}$ & $\begin{array}{l}-0.0590 \\
0.0032)\end{array}$ \\
\hline Any older half sibs, dad & & & $\begin{array}{c}-0.0203 \\
(0.0036)\end{array}$ & $\begin{array}{l}-0.0211 \\
(0.0036)\end{array}$ & $\begin{array}{c}-0.0211 \\
(0.0036)\end{array}$ \\
\hline Older full sibs & & & & $\begin{array}{c}-0.0263 \\
(0.0006)\end{array}$ & $\begin{array}{c}-0.0263 \\
(0.0006)\end{array}$ \\
\hline With father after separation & & & & & $\begin{array}{l}-0.0145 \\
(0.0121)\end{array}$ \\
\hline With neither parent after sep. & & & & & $\begin{array}{c}-0.0305 \\
(0.0251)\end{array}$ \\
\hline Adj R-sq. & 0.002 & 0.002 & 0.019 & 0.050 & 0.050 \\
\hline
\end{tabular}


Table 4. Sibling-differences. Dependent variable: earnings- weighted education. (Standard errors in parentheses.) $\mathrm{N}=104,139$

\begin{tabular}{|c|c|c|c|c|}
\hline & Model 1 & Model 2 & Model3 & Model 4 \\
\hline Constant & $\begin{array}{l}-0.1017 \\
(0.0590)\end{array}$ & $\begin{array}{l}-0.1050 \\
(0.0592)\end{array}$ & $\begin{array}{c}-0.1093 \\
(0.0592)\end{array}$ & $\begin{array}{l}-0.1081 \\
(0.0592)\end{array}$ \\
\hline Age & $\begin{array}{c}0.0135 \\
(0.0029)\end{array}$ & $\begin{array}{r}0.0136 \\
(0.0029)\end{array}$ & $\begin{array}{c}0.0138 \\
(0.0029)\end{array}$ & $\begin{array}{c}0.0136 \\
(0.0029)\end{array}$ \\
\hline Age sq./1000 & $\begin{array}{l}-0.1389 \\
(0.0356)\end{array}$ & $\begin{array}{c}-0.1403 \\
(0.0357)\end{array}$ & $\begin{array}{l}-0.1388 \\
(0.0357\end{array}$ & $\begin{array}{l}-0.1382 \\
(0.0357)\end{array}$ \\
\hline Teenage mum & & & $\begin{array}{l}-0.0029 \\
(0.0044)\end{array}$ & $\begin{array}{l}-0.0028 \\
(0.0044)\end{array}$ \\
\hline Old dad (>44 at birth) & & & $\begin{array}{c}0.0134 \\
(0.0048)\end{array}$ & $\begin{array}{c}0.0134 \\
(0.0048)\end{array}$ \\
\hline Female & $\begin{array}{l}-0.0073 \\
(0.0012)\end{array}$ & $\begin{array}{l}-0.0073 \\
(0.0012)\end{array}$ & $\begin{array}{c}-0.0073 \\
(0.0012)\end{array}$ & $\begin{array}{l}-0.0073 \\
(0.0012)\end{array}$ \\
\hline Separation & $\begin{array}{c}0.0038 \\
(0.0058)\end{array}$ & $\begin{array}{c}0.0137 \\
(0.0149)\end{array}$ & $\begin{array}{c}0.0143 \\
(0.0150)\end{array}$ & $\begin{array}{c}0.0164 \\
(0.0151)\end{array}$ \\
\hline Age at separation & & $\begin{array}{l}-0.0009 \\
(0.0012)\end{array}$ & $\begin{array}{l}-0.0009 \\
(0.0012)\end{array}$ & $\begin{array}{l}-0.0009 \\
(0.0012)\end{array}$ \\
\hline With father after separation & & & & $\begin{array}{l}-0.0201 \\
(0.0152)\end{array}$ \\
\hline With neither parent after sep. & & & & $\begin{array}{c}0.0012 \\
(0.0214)\end{array}$ \\
\hline R-sq. within & 0.0036 & 0.0036 & 0.0037 & 0.0038 \\
\hline
\end{tabular}

Note: Only full siblings included. Persons without siblings excluded. 
Table 5. Cross-section regressions. Dependent variable: earnings-weighted education. (Standard errors in parentheses.) Persons born in 1959 or later. $\mathrm{N}=24,485$.

\begin{tabular}{|c|c|c|c|c|c|}
\hline & Model 1 & Model 2 & Model 3 & Model 4 & Model 5 \\
\hline Constant & $\begin{array}{c}-0.6311 \\
(0.8245)\end{array}$ & $\begin{array}{l}-0.5370 \\
(0.8314)\end{array}$ & $\begin{array}{l}-0.4848 \\
(0.8234)\end{array}$ & $\begin{array}{c}-0.7026 \\
(0.8154)\end{array}$ & $\begin{array}{l}-0.7319 \\
(0.8154)\end{array}$ \\
\hline Age & $\begin{array}{c}0.0515 \\
(0.0472)\end{array}$ & $\begin{array}{c}0.0461 \\
(0.0476)\end{array}$ & $\begin{array}{c}0.0389 \\
(0.0471)\end{array}$ & $\begin{array}{c}0.0540 \\
(0.0467)\end{array}$ & $\begin{array}{c}0.0556 \\
(0.0467)\end{array}$ \\
\hline Age sq./1000 & $\begin{array}{c}-0.7696 \\
(0.6743)\end{array}$ & $\begin{array}{l}-0.6930 \\
(0.6799)\end{array}$ & $\begin{array}{l}-0.5976 \\
(0.6734)\end{array}$ & $\begin{array}{c}-0.8430 \\
(0.6669)\end{array}$ & $\begin{array}{c}-0.8662 \\
(0.6669)\end{array}$ \\
\hline Female & $\begin{array}{c}-0.0092 \\
(0.0023)\end{array}$ & $\begin{array}{l}-0.0092 \\
(0.0023)\end{array}$ & $\begin{array}{l}-0.0094 \\
(0.0022)\end{array}$ & $\begin{array}{c}-0.0094 \\
(0.0022)\end{array}$ & $\begin{array}{l}-0.0094 \\
(0.0022)\end{array}$ \\
\hline Separation & $\begin{array}{c}-0.0446 \\
(0.0038)\end{array}$ & $\begin{array}{c}-0.0542 \\
(0.0115)\end{array}$ & $\begin{array}{l}-0.0391 \\
(0.0114)\end{array}$ & $\begin{array}{c}-0.0481 \\
(0.0113)\end{array}$ & $\begin{array}{c}-0.0432 \\
(0.0115)\end{array}$ \\
\hline Age at separation & & $\begin{array}{c}0.00114 \\
(0.00129)\end{array}$ & $\begin{array}{c}0.0008 \\
(0.0013)\end{array}$ & $\begin{array}{c}0.0016 \\
(0.0013)\end{array}$ & $\begin{array}{c}0.0013 \\
(0.0013)\end{array}$ \\
\hline Mum's age at birth & & & $\begin{array}{c}0.0044 \\
(0.0003)\end{array}$ & $\begin{array}{c}0.0047 \\
(0.0003)\end{array}$ & $\begin{array}{c}0.0047 \\
(0.0003)\end{array}$ \\
\hline Teenage mum & & & $\begin{array}{c}-0.0269 \\
(0.0067)\end{array}$ & $\begin{array}{l}-0.0250 \\
(0.0066)\end{array}$ & $\begin{array}{c}-0.0249 \\
(0.0066)\end{array}$ \\
\hline Dad's age at birth & & & $\begin{array}{r}-0.0010 \\
(0.0003)\end{array}$ & $\begin{array}{c}-0.0006 \\
(0.0003)\end{array}$ & $\begin{array}{l}-0.0005 \\
(0.0003)\end{array}$ \\
\hline Old dad (>44 at birth) & & & $\begin{array}{l}-0.0284 \\
(0.0068)\end{array}$ & $\begin{array}{c}-0.0236 \\
(0.0068)\end{array}$ & $\begin{array}{l}-0.0236 \\
(0.0068)\end{array}$ \\
\hline Any older half sibs, mum & & & $\begin{array}{l}-0.0516 \\
(0.0044)\end{array}$ & $\begin{array}{c}-0.0603 \\
(0.0043)\end{array}$ & $\begin{array}{c}-0.0603 \\
(0.0043)\end{array}$ \\
\hline Any older half sibs, dad & & & $\begin{array}{l}-0.0171 \\
(0.0048)\end{array}$ & $\begin{array}{c}-0.0225 \\
(0.0047)\end{array}$ & $\begin{array}{l}-0.0225 \\
(0.0047)\end{array}$ \\
\hline Older full sibs & & & & $\begin{array}{l}-0.0217 \\
(0.0010)\end{array}$ & $\begin{array}{l}-0.0216 \\
(0.0010)\end{array}$ \\
\hline With father after separation & & & & & $\begin{array}{l}-0.0055 \\
(0.0106)\end{array}$ \\
\hline With neither parent after sep. & & & & & $\begin{array}{l}-0.0436 \\
(0.0177)\end{array}$ \\
\hline Adj R-sq. & 0.006 & 0.006 & 0.026 & 0.044 & 0.045 \\
\hline
\end{tabular}


Table 6. Sibling-differences. Dependent variable: earnings- weighted education. Persons born in 1959 or later (Standard errors in parentheses.) $\mathrm{N}=36,543$

\begin{tabular}{|c|c|c|c|c|}
\hline & Model 1 & Model 2 & Model3 & Model 4 \\
\hline Constant & $\begin{array}{c}-0.4897 \\
(1.0146)\end{array}$ & $\begin{array}{c}-0.5948 \\
(1.0199)\end{array}$ & $\begin{array}{l}-0.6406 \\
(1.0203)\end{array}$ & $\begin{array}{l}-0.6375 \\
(1.0206)\end{array}$ \\
\hline Age & $\begin{array}{r}0.0362 \\
(0.0583)\end{array}$ & $\begin{array}{r}0.0419 \\
(0.0586)\end{array}$ & $\begin{array}{c}0.0440 \\
(0.0586)\end{array}$ & $\begin{array}{c}0.0439 \\
(0.0586)\end{array}$ \\
\hline Age sq./1000 & $\begin{array}{l}-0.4591 \\
(0.8364)\end{array}$ & $\begin{array}{l}-0.5379 \\
(0.8401)\end{array}$ & $\begin{array}{l}-0.5625 \\
(0.8402)\end{array}$ & $\begin{array}{l}-0.5599 \\
(0.8405)\end{array}$ \\
\hline Teenage mum & & & $\begin{array}{l}-0.0105 \\
(0.0108)\end{array}$ & $\begin{array}{l}-0.0105 \\
(0.0108)\end{array}$ \\
\hline Old dad (>44 at birth) & & & $\begin{array}{c}0.0387 \\
(0.0193)\end{array}$ & $\begin{array}{c}0.0388 \\
(0.0192)\end{array}$ \\
\hline Female & $\begin{array}{l}-0.0034 \\
(0.0031)\end{array}$ & $\begin{array}{l}-0.0034 \\
(0.0031)\end{array}$ & $\begin{array}{l}-0.0033 \\
(0.0031)\end{array}$ & $\begin{array}{l}-0.0033 \\
(0.0031)\end{array}$ \\
\hline Separation & $\begin{array}{r}0.0300 \\
(0.0173)\end{array}$ & $\begin{array}{r}0.0724 \\
(0.0453)\end{array}$ & $\begin{array}{c}0.0712 \\
(0.0453)\end{array}$ & $\begin{array}{c}0.0730 \\
(0.0459)\end{array}$ \\
\hline Age at separation & & $\begin{array}{l}-0.0039 \\
(0.0038)\end{array}$ & $\begin{array}{l}-0.0038 \\
(0.0038)\end{array}$ & $\begin{array}{l}-0.0038 \\
(0.0038)\end{array}$ \\
\hline With father after separation & & & & $\begin{array}{l}-0.0118 \\
(0.0426)\end{array}$ \\
\hline With neither parent after sep. & & & & $\begin{array}{c}0.0036 \\
(0.0999)\end{array}$ \\
\hline R-sq. within & 0.0028 & 0.0030 & 0.0036 & 0.0036 \\
\hline
\end{tabular}

Note: Only full siblings included. Persons without siblings excluded. 
Table 7. Cross-section regressions. Dependent variable: earnings-weighted education. (Standard errors in parentheses.) Persons without full sibling. $\mathrm{N}=7,705$.

\begin{tabular}{|c|c|c|c|c|}
\hline & Model 1 & Model 2 & Model 3 & Model 5 \\
\hline Constant & $\begin{array}{c}0.5389 \\
(0.2496)\end{array}$ & $\begin{array}{c}0.5337 \\
(0.2496)\end{array}$ & $\begin{array}{c}0.4564 \\
(0.2470)\end{array}$ & $\begin{array}{c}0.4532 \\
(0.2471)\end{array}$ \\
\hline Age & $\begin{array}{c}-0.0151 \\
(0.0128)\end{array}$ & $\begin{array}{l}-0.0149 \\
(0.0128)\end{array}$ & $\begin{array}{c}-0.0142 \\
(0.0127)\end{array}$ & $\begin{array}{l}-0.0140 \\
(0.0127)\end{array}$ \\
\hline Age sq./1000 & $\begin{array}{c}0.1951 \\
(0.1640)\end{array}$ & $\begin{array}{c}0.1932 \\
(0.1640)\end{array}$ & $\begin{array}{c}0.1721 \\
(0.1626)\end{array}$ & $\begin{array}{c}0.1700 \\
(0.1626)\end{array}$ \\
\hline Female & $\begin{array}{c}-0.0197 \\
(0.0041)\end{array}$ & $\begin{array}{l}-0.0197 \\
(0.0041)\end{array}$ & $\begin{array}{l}-0.0201 \\
(0.0041)\end{array}$ & $\begin{array}{l}-0.0201 \\
(0.0041)\end{array}$ \\
\hline Separation & $\begin{array}{c}-0.0521 \\
(0.0067)\end{array}$ & $\begin{array}{l}-0.0347 \\
(0.0181)\end{array}$ & $\begin{array}{l}-0.0151 \\
(0.0151)\end{array}$ & $\begin{array}{l}-0.0149 \\
(0.0182)\end{array}$ \\
\hline Age at separation & - & $\begin{array}{l}-0.0022 \\
(0.0021)\end{array}$ & $\begin{array}{r}-0.0027 \\
(0.0021)\end{array}$ & $\begin{array}{r}-0.0023 \\
(0.0021)\end{array}$ \\
\hline Mum's age at birth & - & & $\begin{array}{c}0.0031 \\
(0.0005)\end{array}$ & $\begin{array}{c}0.0031 \\
(0.0005)\end{array}$ \\
\hline Teenage mum & - & & $\begin{array}{l}-0.0316 \\
(0.0138)\end{array}$ & $\begin{array}{l}-0.0313 \\
(0.0138)\end{array}$ \\
\hline Dad's age at birth & - & & $\begin{array}{c}0.0000 \\
(0.0000)\end{array}$ & $\begin{array}{c}0.0000 \\
(0.0005)\end{array}$ \\
\hline Old dad (>44 at birth) & - & & $\begin{array}{l}-0.0120 \\
(0.0107)\end{array}$ & $\begin{array}{l}-0.0123 \\
(0.0107)\end{array}$ \\
\hline Any older half sibs, mum & - & & $\begin{array}{l}-0.0548 \\
(0.0056)\end{array}$ & $\begin{array}{l}-0.0546 \\
(0.0056)\end{array}$ \\
\hline Any older half sibs, dad & - & & $\begin{array}{l}-0.0221 \\
(0.0075)\end{array}$ & $\begin{array}{r}-0.0224 \\
(0.0075)\end{array}$ \\
\hline With father after separation & & & & $\begin{array}{l}-0.0258 \\
(0.0208)\end{array}$ \\
\hline With neither parent after sep. & & & & $\begin{array}{l}-0.0173 \\
(0.0343)\end{array}$ \\
\hline Adj R-sq. & 0.011 & 0.011 & 0.033 & 0.033 \\
\hline
\end{tabular}

Note: As these persons have no older full siblings, there is no Model 4 in the table. 
Table 8. Sibling-differences. Dependent variable: earnings-weighted education. Siblings born at least five years apart (Standard errors in parentheses.) $\mathrm{N}=19,090$

\begin{tabular}{|c|c|c|c|c|}
\hline & Model 1 & Model 2 & Model 3 & Model 4 \\
\hline Constant & $\begin{array}{r}0.4694 \\
(0.2934)\end{array}$ & $\begin{array}{r}0.4664 \\
(0.2935)\end{array}$ & $\begin{array}{c}0.4459 \\
(0.2940)\end{array}$ & $\begin{array}{l}-0.4479 \\
(0.2941)\end{array}$ \\
\hline Age & $\begin{array}{l}-0.0138 \\
(0.0154)\end{array}$ & $\begin{array}{l}-0.0137 \\
(0.0154)\end{array}$ & $\begin{array}{l}-0.0130 \\
(0.0155)\end{array}$ & $\begin{array}{l}-0.0131 \\
(0.0155)\end{array}$ \\
\hline Age sq./1000 & $\begin{array}{r}0.1722 \\
(0.2036)\end{array}$ & $\begin{array}{r}0.1723 \\
(0.2036)\end{array}$ & $\begin{array}{c}0.1663 \\
(0.2037)\end{array}$ & $\begin{array}{l}-0.0168 \\
(0.2038)\end{array}$ \\
\hline Teenage mum & & & a) & a) \\
\hline Old dad (>44 at birth) & & & $\begin{array}{c}0.0117 \\
(0.0103)\end{array}$ & $\begin{array}{c}0.0117 \\
(0.0103)\end{array}$ \\
\hline Female & $\begin{array}{l}-0.0042 \\
(0.0036)\end{array}$ & & $\begin{array}{l}-0.0042 \\
(0.0036)\end{array}$ & $\begin{array}{l}-0.0033 \\
(0.0031)\end{array}$ \\
\hline Separation & $\begin{array}{l}-0.0080 \\
(0.0173)\end{array}$ & $\begin{array}{r}0.0164 \\
(0.0465)\end{array}$ & $\begin{array}{c}0.0183 \\
(0.0465)\end{array}$ & $\begin{array}{c}0.0191 \\
(0.0473)\end{array}$ \\
\hline Age at separation & & $\begin{array}{l}-0.0022 \\
(0.0039)\end{array}$ & $\begin{array}{l}-0.0023 \\
(0.0039)\end{array}$ & $\begin{array}{l}-0.0024 \\
(0.0039)\end{array}$ \\
\hline With father after separation & & & & $\begin{array}{c}0.0034 \\
(0.0396)\end{array}$ \\
\hline With neither parent after sep. & & & & $\begin{array}{c}0.0483 \\
(0.0896)\end{array}$ \\
\hline R-sq. within & 0.0007 & 0.0008 & 0.0011 & 0.0012 \\
\hline
\end{tabular}


Table 9. Sbling-differences. Dependent variable: earnings-weighted education. Indicators for birth-order included (Standard errors in parentheses.) N=104,139

\begin{tabular}{|c|c|c|c|c|}
\hline & Model 1 & Model 2 & Model 3 & Model 4 \\
\hline Constant & $\begin{array}{l}-0.0512 \\
(0.0651)\end{array}$ & $\begin{array}{c}0.0474 \\
(0.0651)\end{array}$ & $\begin{array}{c}0.0427 \\
(0.0652)\end{array}$ & $\begin{array}{c}0.0436 \\
(0.0652)\end{array}$ \\
\hline Age & $\begin{array}{c}0.0081 \\
(0.0031)\end{array}$ & $\begin{array}{c}0.0083 \\
(0.0031)\end{array}$ & $\begin{array}{c}0.0084 \\
(0.0031)\end{array}$ & $\begin{array}{c}0.0083 \\
(0.0031)\end{array}$ \\
\hline Age sq./1000 & $\begin{array}{l}-0.1007 \\
(0.0372)\end{array}$ & $\begin{array}{l}-0.1024 \\
(0.0372)\end{array}$ & $\begin{array}{l}-0.1018 \\
(0.0372)\end{array}$ & $\begin{array}{l}-0.1012 \\
(0.0372)\end{array}$ \\
\hline Oldest & $\begin{array}{r}0.0147 \\
(0.0017)\end{array}$ & $\begin{array}{c}0.0147 \\
(0.0017)\end{array}$ & $\begin{array}{c}0.0145 \\
(0.0017)\end{array}$ & $\begin{array}{c}0.0145 \\
(0.0017)\end{array}$ \\
\hline Youngest & $\begin{array}{l}-0.0066 \\
(0.0017)\end{array}$ & $\begin{array}{l}-0.0067 \\
(0.0017)\end{array}$ & $\begin{array}{c}-0.0068 \\
(0.0017)\end{array}$ & $\begin{array}{l}-0.0068 \\
(0.0017)\end{array}$ \\
\hline Teenage mum & & & $\begin{array}{l}-0.0054 \\
(0.0044)\end{array}$ & $\begin{array}{l}-0.0053 \\
(0.0043)\end{array}$ \\
\hline Old dad (>44 at birth) & & & $\begin{array}{c}0.0095 \\
(0.0048)\end{array}$ & $\begin{array}{c}0.0094 \\
(0.0048)\end{array}$ \\
\hline Female & $\begin{array}{l}-0.0073 \\
(0.0012)\end{array}$ & $\begin{array}{l}-0.0073 \\
(0.0012)\end{array}$ & $\begin{array}{l}-0.0073 \\
(0.0012)\end{array}$ & $\begin{array}{l}-0.0073 \\
(0.0012)\end{array}$ \\
\hline Separation & $\begin{array}{r}0.0040 \\
(0.0058)\end{array}$ & $\begin{array}{r}0.0199 \\
(0.0150)\end{array}$ & $\begin{array}{c}0.0198 \\
(0.0150)\end{array}$ & $\begin{array}{c}0.0218 \\
(0.0151)\end{array}$ \\
\hline Age at separation & & $\begin{array}{l}-0.0014 \\
(0.0012)\end{array}$ & $\begin{array}{c}-0.0014 \\
(0.0012)\end{array}$ & $\begin{array}{l}-0.0014 \\
(0.0012)\end{array}$ \\
\hline With father after separation & & & & $\begin{array}{l}-0.0199 \\
(0.0152)\end{array}$ \\
\hline With neither parent after sep. & & & & $\begin{array}{c}0.0019 \\
(0.0213)\end{array}$ \\
\hline R-sq. within & 0.0058 & 0.0058 & 0.0059 & 0.0060 \\
\hline
\end{tabular}

Note: Only full siblings included. Persons without siblings excluded. a) Too few cases. 
Table 10. Cross-section regressions. Dependent variable: earnings-weighted education. (Standard errors in parentheses.) Individuals in families that identify the separation coefficient in the siblingdifference analysis. $\mathrm{N}=2,632$.

\begin{tabular}{|c|c|c|c|c|c|}
\hline & Model 1 & Model 2 & Model 3 & Model 4 & Model 5 \\
\hline Constant & $\begin{array}{c}0.1667 \\
(0.2804)\end{array}$ & $\begin{array}{c}0.2268 \\
(0.2866)\end{array}$ & $\begin{array}{c}0.2366 \\
(0.2851)\end{array}$ & $\begin{array}{c}0.3568 \\
(0.2802)\end{array}$ & $\begin{array}{c}0.3565 \\
(0.2807)\end{array}$ \\
\hline Age & $\begin{array}{c}0.0026 \\
(0.0138)\end{array}$ & $\begin{array}{l}-0.0001 \\
(0.0141)\end{array}$ & $\begin{array}{l}-0.0027 \\
(0.0140)\end{array}$ & $\begin{array}{c}-0.0085 \\
(0.0138)\end{array}$ & $\begin{array}{l}-0.0087 \\
(0.0138)\end{array}$ \\
\hline Age sq./1000 & $\begin{array}{c}-0.0054 \\
(0.1700)\end{array}$ & $\begin{array}{l}-0.0231 \\
(0.1717)\end{array}$ & $\begin{array}{c}0.0052 \\
(0.1717)\end{array}$ & $\begin{array}{c}0.0653 \\
(0.1687)\end{array}$ & $\begin{array}{c}0.0686 \\
(0.1688)\end{array}$ \\
\hline Female & $\begin{array}{c}-0.0141 \\
(0.0059)\end{array}$ & $\begin{array}{l}-0.0141 \\
(0.0059)\end{array}$ & $\begin{array}{l}-0.0132 \\
(0.0058)\end{array}$ & $\begin{array}{l}-0.0119 \\
(0.0057)\end{array}$ & $\begin{array}{l}-0.0118 \\
(0.0057)\end{array}$ \\
\hline Separation & $\begin{array}{c}-0.0131 \\
(0.0070)\end{array}$ & $\begin{array}{l}-0.0392 \\
(0.0266)\end{array}$ & $\begin{array}{l}-0.0720 \\
(0.0277)\end{array}$ & $\begin{array}{l}-0.0083 \\
(0.0279)\end{array}$ & $\begin{array}{l}-0.0129 \\
(0.0280)\end{array}$ \\
\hline Age at separation & & $\begin{array}{c}0.0023 \\
(0.0023)\end{array}$ & $\begin{array}{c}0.0041 \\
(0.0023)\end{array}$ & $\begin{array}{c}0.0003 \\
(0.0029)\end{array}$ & $\begin{array}{c}0.0012 \\
(0.0023)\end{array}$ \\
\hline Mum's age at birth & & & $\begin{array}{c}0.0039 \\
(0.0009)\end{array}$ & $\begin{array}{c}0.0045 \\
(0.0009)\end{array}$ & $\begin{array}{c}0.0044 \\
(0.0009)\end{array}$ \\
\hline Teenage mum & & & $\begin{array}{r}-0.0005 \\
(0.0164)\end{array}$ & $\begin{array}{c}0.0013 \\
(0.0161)\end{array}$ & $\begin{array}{c}0.0016 \\
(0.0161)\end{array}$ \\
\hline Dad's age at birth & & & $\begin{array}{r}-0.0015 \\
(0.0007)\end{array}$ & $\begin{array}{c}-0.0006 \\
(0.0007)\end{array}$ & $\begin{array}{l}-0.0005 \\
(0.0007)\end{array}$ \\
\hline Old dad (>44 at birth) & & & $\begin{array}{c}0.0099 \\
(0.0198)\end{array}$ & $\begin{array}{c}0.0128 \\
(0.0194)\end{array}$ & $\begin{array}{c}0.0139 \\
(0.0195)\end{array}$ \\
\hline Any older half sibs, mum & & & $\begin{array}{l}-0.0340 \\
(0.0095)\end{array}$ & $\begin{array}{c}-0.0393 \\
(0.0093)\end{array}$ & $\begin{array}{l}-0.0381 \\
(0.0094)\end{array}$ \\
\hline Any older half sibs, dad & & & $\begin{array}{l}-0.0315 \\
(0.0124)\end{array}$ & $\begin{array}{l}-0.0306 \\
(0.0122)\end{array}$ & $\begin{array}{l}-0.0321 \\
(0.0122)\end{array}$ \\
\hline Older full sibs & & & & $\begin{array}{l}-0.0248 \\
(0.0025)\end{array}$ & $\begin{array}{l}-0.0244 \\
(0.0025)\end{array}$ \\
\hline With father after separation & & & & & $\begin{array}{l}-0.0264 \\
(0.0120)\end{array}$ \\
\hline With neither parent after sep. & & & & & $\begin{array}{l}-0.0303 \\
(0.0212)\end{array}$ \\
\hline Adj R-sq. & 0.003 & 0.003 & 0.016 & 0.051 & 0.052 \\
\hline
\end{tabular}


Appendix. Means and frequencies for the individuals in families that identify the separation coefficient in the sibling-difference analysis. Standard-deviations for earnings-weighted education in parentheses.

Female

Separation

0.469

Age at separation

Teenage mum

0.037

Old dad

Mother's age at birth

Father's age at birth

Mother aft. separ.

Father aft. separ

No parent aft. sep

\# of full siblings

\# older full siblings

\# of half siblings

0.62

Any older half

siblings mum's side

0.110

Any older half

siblings dad's side

Earnings- weighted

0.170

education

(0.150)

\# of observations 


\section{IZA Discussion Papers}

\begin{tabular}{|c|c|c|c|c|}
\hline No. & Author(s) & Title & Area & Date \\
\hline 627 & $\begin{array}{l}\text { J. Boone } \\
\text { J. C. van Ours }\end{array}$ & Cyclical Fluctuations in Workplace Accidents & 5 & $11 / 02$ \\
\hline 628 & $\begin{array}{l}\text { R. Breunig } \\
\text { D. A. Cobb-Clark } \\
\text { Y. Dunlop } \\
\text { M. Terrill }\end{array}$ & $\begin{array}{l}\text { Assisting the Long-Term Unemployed: Results } \\
\text { from a Randomized Trial }\end{array}$ & 6 & $11 / 02$ \\
\hline 629 & $\begin{array}{l}\text { I. N. Gang } \\
\text { K. Sen } \\
\text { M.-S. Yun }\end{array}$ & Caste, Ethnicity and Poverty in Rural India & 2 & $11 / 02$ \\
\hline 630 & W. Arulampalam & $\begin{array}{l}\text { State Dependence in Unemployment Incidence: } \\
\text { Evidence for British Men Revisited }\end{array}$ & 3 & $11 / 02$ \\
\hline 631 & $\begin{array}{l}\text { H. O. Duleep } \\
\text { M. Regets }\end{array}$ & $\begin{array}{l}\text { The Elusive Concept of Immigrant Quality: } \\
\text { Evidence from 1970-1990 }\end{array}$ & 1 & $11 / 02$ \\
\hline 632 & $\begin{array}{l}\text { B. Cockx } \\
\text { M. Dejemeppe }\end{array}$ & $\begin{array}{l}\text { Duration Dependence in the Exit Rate out of } \\
\text { Unemployment in Belgium: Is It True or } \\
\text { Spurious? }\end{array}$ & 2 & $11 / 02$ \\
\hline 633 & A. D. Kugler & Employee Referrals and Efficiency Wages & 5 & $11 / 02$ \\
\hline 634 & $\begin{array}{l}\text { A. D. Kugler } \\
\text { R. M. Sauer }\end{array}$ & $\begin{array}{l}\text { Doctors Without Borders: The Returns to an } \\
\text { Occupational License for Soviet Immigrant } \\
\text { Physicians in Israel }\end{array}$ & 1 & $11 / 02$ \\
\hline 635 & $\begin{array}{l}\text { M. Karanassou } \\
\text { D. J. Snower }\end{array}$ & An Anatomy of the Phillips Curve & 3 & $11 / 02$ \\
\hline 636 & $\begin{array}{l}\text { M. Karanassou } \\
\text { H. Sala } \\
\text { D. J. Snower }\end{array}$ & $\begin{array}{l}\text { A Reappraisal of the Inflation-Unemployment } \\
\text { Tradeoff }\end{array}$ & 3 & $11 / 02$ \\
\hline 637 & $\begin{array}{l}\text { H. Bonin } \\
\text { W. Kempe } \\
\text { H. Schneider }\end{array}$ & $\begin{array}{l}\text { Household Labor Supply Effects of Low-Wage } \\
\text { Subsidies in Germany }\end{array}$ & 3 & $11 / 02$ \\
\hline 638 & $\begin{array}{l}\text { L. McLeod } \\
\text { M. R. Veall }\end{array}$ & $\begin{array}{l}\text { The Dynamics of Food Deprivation and Overall } \\
\text { Health: Evidence from the Canadian National } \\
\text { Population Health Survey }\end{array}$ & 2 & $11 / 02$ \\
\hline 639 & G. Saint-Paul & Are Intellectual Property Rights Unfair? & 3 & $11 / 02$ \\
\hline 640 & $\begin{array}{l}\text { J. Hartog } \\
\text { N. Jonker } \\
\text { H. van Ophem }\end{array}$ & $\begin{array}{l}\text { Dual Track or Academic Route for Auditors: } \\
\text { Does It Matter? }\end{array}$ & 6 & $11 / 02$ \\
\hline 641 & $\begin{array}{l}\text { J. Hartog } \\
\text { L. Diaz Serrano }\end{array}$ & $\begin{array}{l}\text { Earning Risk and Demand for Higher Education: } \\
\text { A Cross-Section Test for Spain }\end{array}$ & 2 & $11 / 02$ \\
\hline 642 & $\begin{array}{l}\text { J. Hartog } \\
\text { A. Zorlu }\end{array}$ & $\begin{array}{l}\text { The Effect of Immigration on Wages in Three } \\
\text { European Countries }\end{array}$ & 1 & $11 / 02$ \\
\hline 643 & $\begin{array}{l}\text { A. Björklund } \\
\text { M. Sundström }\end{array}$ & $\begin{array}{l}\text { Parental Separation and Children's Educational } \\
\text { Attainment: A Siblings Approach }\end{array}$ & 6 & $11 / 02$ \\
\hline
\end{tabular}

An updated list of IZA Discussion Papers is available on the center's homepage www.iza.org. 